\title{
Contágio, doença e evitação em uma associação de ex-bebedores: o caso dos Alcoólicos Anônimos
}

\author{
Edemilson Antunes de Campos \\ Doutor em Ciências Sociais - UFSCar
}

RESUMO: O objetivo deste artigo é analisar a construção da noção de doença alcoólica em uma associação de ex-bebedores: os Alcoólicos Anônimos (A.A.). A partir de pesquisa etnográfica realizada com familiares e membros do grupo Sapopemba de A.A., localizado em bairro da periferia da cidade de São Paulo, no Brasil, enfatiza-se o papel dessa entidade como um espaço privilegiado para o estudo antropológico da experiência do alcoolismo, a partir de uma perspectiva êmica, isto é, tal como ela é vivenciada e gerida por aqueles que se reconhecem como "doentes alcoólicos em recuperação", ao mesmo tempo em que se destaca a possibilidade de "contágio" da doença alcoólica, ligada às representações construídas sobre o álcool e o alcoolismo. Com efeito, o alcoolismo é entendido como uma doença física e moral que, além de atingir o indivíduo considerado doente, também afeta o conjunto das relaçôes sociais - familiares e profissionais -, nas quais ele está envolvido. Como conseqüência, analisa-se o modelo terapêutico de A.A. como um "sistema de evitações", que permite ao doente alcoólico construir uma ordem de sentido, no interior da qual se opera a construção simbólica da experiência da doença, cujo objetivo é possibilitar o controle da doença alcoólica e o resgate dos laços sociais - na família e no trabalho -, perdidos no tempo do alcoolismo ativo.

PALAVRAS-CHAVE: Alcoólicos Anônimos, alcoolismo, doença, sistema de evitaçôes, teoria cultural do contágio. 
Edemilson Antunes de Campos. Contágio, doença e evitação...

\section{Apresentação}

O objetivo deste artigo é apresentar uma reflexão sobre o modelo terapêutico construído pela irmandade de Alcoólicos Anônimos (A.A.) ${ }^{1}$ para dar conta da chamada "doença do alcoolismo", entendida como uma "doença contagiosa", isto é, uma doença que, além de atingir o indivíduo considerado doente, também afeta todos aqueles que convivem em seu redor, notadamente seus familiares. Seguindo a linha dos trabalhos de Douglas (1992) e Fainzang (1996), ambos preocupados em pensar uma teoria cultural do contágio no contexto da Aids e do alcoolismo, respectivamente, busca-se traçar os contornos de uma definição antropológica e cultural do contágio, relacionada às representações elaboradas pelos AAs e também por seus familiares sobre o álcool e o alcoolismo.

O alcoolismo é considerado um dos mais sérios problemas de saúde pública da atualidade, despertando a atenção de autoridades médicas e sanitárias de diversos países. Segundo os dados do I Levantamento Domiciliar sobre o Uso de Drogas Psicotrópicas no Brasil, realizado em 2001 pelo Centro Brasileiro de Informações sobre Drogas Psicotrópicas (Cebrid) (2002), da Universidade Federal de São Paulo (Unifesp), em conjunto com a Secretaria Nacional AntiDrogas (Senad), envolvendo as 107 maiores cidades do País, 11,2\% da população brasileira é dependente do álcool (2002, p. 37), e a prevalência da dependência está na faixa etária de 18 a 24 anos, em um total de 15,5\% (2002, p. 47).

É nesse contexto que o par alcoolismo/doença começa a fazer parte do campo de reflexões das ciências sociais, despertando o interesse de pesquisadores nacionais e internacionais (Campos, 2004; Fainzang, 1996; Jovelin \& Oreskovic, 2002; Garcia, 2004; Mota, 2004; Neves, 2004), deixando de ser um objeto privilegiado apenas pela medicina epidemiológica e psiquiátrica. 
Revista de Antropologia, São Paulo, USP, 2005, v. 48 no 1.

O alcoolismo revela-se um importante objeto de estudo antropológico, notadamente quando os próprios "nativos" o entendem como doença, tal como ocorre em A.A. Durante suas reuniōes, os ex-bebedores se reconhecem como "doentes alcoólicos": "Sou um doente alcoólico em recuperação e venho às reuniōes para deixar de ser aquele cachaceiro que eu era", dizem os AAs, assinalando a passagem de uma posição na qual o beber considerado abusivo é estigmatizado para uma posição na qual o ato de beber é entendido de maneira "patológica".

Com essa medida, o par alcoolismo/doença é relativizado e considerado dentro de um contexto cultural específico. Os grupos de A.A. podem, então, ser compreendidos como um universo social, com ritos, representaçóes, símbolos e valores próprios, que proporciona a seus membros tanto a possibilidade de reorganizarem suas condutas como a de atribuírem significados próprios ao "problema" do alcoolismo, ao mesmo tempo em que constroem uma representação específica de si mesmos.

A irmandade de A.A. torna-se, assim, um local privilegiado para o estudo das representaçóes e dos significados produzidos em torno da chamada "doença alcoólica". Isso porque, nos espaços construídos por seus membros, são vivenciados, como sublinha Neves, "os modos de construção do alcoólico como identidade redentora, graças à entre-ajuda ou à solução coletiva"' (2004, p. 12; grifo do original), de forma que os associados podem falar de si mesmos sem as pressóes da culpa e do preconceito.

Ao analisar o modelo terapêutico de A.A., pode-se compreender o alcoolismo de uma maneira êmica, isto é, tal como ele é pensado e gerido por aqueles que se reconhecem como "doentes alcoólicos em recuperação". Com isso, é possível entender a maneira pela qual os AAs abordam o alcoolismo, como eles o explicam, vivenciam-no e tentam superá-lo, concebendo-o como uma "doença contagiosa", que afeta o conjunto das relaçōes sociais - familiares e profissionais -, nas quais o indivíduo doente está envolvido. 
Edemilson Antunes de Campos. Contágio, doença e evitação...

\section{A pesquisa de campo: encontrando os Alcoólicos Anônimos}

Estas reflexões são fundamentadas em uma pesquisa de campo, realizada entre setembro de 2001 e setembro de 2002, no grupo Sapopemba de A.A., que faz parte do $42^{\circ}$ Distrito de Alcoólicos Anônimos do Estado de São Paulo, do Setor A - Capital. ${ }^{3}$ A escolha desse grupo deveu-se ao fato de se tratar de um já consolidado na promoção de reuniōes de recuperação, que acontecem desde a sua fundação, em 16 de março de 1981.

$\mathrm{O}$ encontro com os AAs ocorreu por intermédio de um amigo que, durante uma conversa, na qual relatava meu interesse em fazer uma pesquisa sobre o programa de recuperação do alcoolismo desenvolvido pela entidade, me disse conhecer um grupo próximo à sua residência, localizada na Vila Ema, pertencente ao populoso distrito de Sapopemba, ${ }^{4}$ na zona leste da cidade de São Paulo. Ele também me informou que os AAs se reuniam todas as noites e que poderia lhes fazer uma consulta sobre a possibilidade de eu realizar minha pesquisa ali. Após ele ter consultado os membros do grupo, marcamos um dia para minha ida ao local.

No dia marcado, encontrei-o na estação do metrô Belém e seguimos de ônibus para a sede do grupo. O percurso levou cerca de uma hora, e eu estava preocupado com a pontualidade - é importante ressaltar que todas as reuniōes que tive a possibilidade de participar começaram pontualmente às $20 \mathrm{~h}$-, pois não queria me atrasar no primeiro encontro.

$\mathrm{O}$ itinerário percorrido foi revelando a paisagem típica das periferias das grandes cidades. Posteriormente, percorrendo as ruas do distrito, foi possível discernir traços importantes de sua formação social. O distrito de Sapopemba localiza-se em uma região limítrofe com o parque industrial do ABC, conhecido pela grande concentração de indústrias do setor automobilístico. Essa proximidade, decisiva para a configuração so- 
cial do distrito, foi responsável pelo fluxo migratório, a partir dos anos 50, de um grande contingente populacional, atraído pela promessa de melhores condições de vida.

O bairro concentra uma população majoritariamente trabalhadora, que depende do próprio salário para sua reprodução social, e assemelha-se, em sua forma, aos bairros vizinhos, delineando os contornos de uma paisagem composta de casas simples, ou inacabadas, ou em processo de construção, que servem de local de moradia, ao mesmo tempo, para a própria família e para a de seus filhos, quando estes vêm a se casar. Exemplo disso é o vivido por Jorge, ${ }^{5} 63$ anos, casado, 4 anos de A.A., taxista, que mora com a esposa e os três filhos em uma casa onde, na parte cima, um cômodo foi construído para abrigar a outra filha, o genro e os dois netos.

Além de abrigo para o núcleo familiar, a casa também tem um papel importante, funcionando, muitas vezes, como local de atividade econômica, na maioria das vezes informal, um recurso utilizado como forma de aumentar a renda familiar. ${ }^{6}$ São pequenos estabelecimentos que oferecem os mais variados serviços, tais como conserto de sapatos, venda de salgadinhos, cabeleireiro, costureira, serviços de pedreiro, conserto de geladeiras, de ferro de passar roupas etc. A queda do número de empregos formais, em função das sucessivas crises econômicas vividas nas últimas décadas, foi responsável por colocar um contingente expressivo de trabalhadores da região na situação de risco de perda do emprego, aumentando a fragilidade econômica em que vivem. Percorrendo a avenida Sapopemba, que atravessa, em sua longa extensão, todo o distrito, é possível constatar o aumento da atividade informal pelo grande número de barracas de marreteiro que se distribui em suas calçadas.

Viver no distrito de Sapopemba também permite formular uma visão própria sobre a vida nas periferias das grandes metrópoles: 
Edemilson Antunes de Campos. Contágio, doença e evitação...

Eu percebo que nosso bairro é periferia. Então, na periferia, é aquela dificuldade, a maioria da população toda desempregada. (...) Eu, como sou daqui, cheguei aqui no bairro em 1970, já faz um bocado de anos que eu faço parte dessa comunidade. (...) Eu vejo que não existe um lazer na regiāo, o lugar mais próximo é no Parque do Carmo. Eu vejo uma dificuldade de condução. Aqui em Sapopemba não tem um posto de saúde. (Paulo, 48 anos, casado, 22 anos de A.A., sapateiro, entrevistado em 25 jan. 2005)

No olhar de Paulo, o bairro aparece classificado como periferia, cuja condição se define por meio das dificuldades compartilhadas cotidianamente, dentre as quais se destacam o desemprego e a falta de infra-estrutura de transporte e saúde, tornando mais difícil a luta pela sobrevivência.

Segundo recorte feito a partir dos dados oficiais, relativos ao ano de 2002, o distrito não contava com equipamentos culturais, como salas de cinema, salas de teatro, casas de cultura, centros de cultura, museus e espaços e oficinas culturais. ${ }^{7}$ Todavia, circulando pelas ruas, é possível visualizar uma sociabilidade que se desenvolve em espaços de lazer, os quais instauram uma alteridade em relação ao espaço doméstico e ao local de trabalho. Esse é o caso, por exemplo, dos bares, que, em números expressivos, povoam as esquinas e ruas. $\mathrm{O}$ bar aparece, muitas vezes, como uma das poucas alternativas de lazer para os moradores da região.

$\mathrm{O}$ distrito abriga ainda uma escola de samba - a Combinados de Sapopemba -, da qual fazem parte alguns membros de A.A., e cujos ensaios para o carnaval mobilizam os moradores em seus momentos de lazer. No mês de junho, ocorre o aniversário do distrito, que é comemorado com uma grande festa - a Festa de Sapopemba -, engajando seus moradores nos preparativos necessários à organização e realização. Há também uma igreja católica, centros espíritas e terreiros de umbanda, que convivem com uma quantidade cada vez mais crescente de igrejas evangélicas, instaurando um circuito religioso pelo qual seus moradores 
passam, participando de atividades que, muitas vezes, concorrem com as poucas opções de lazer oferecidas na região. A igreja católica também abriga reuniões de Narcóticos Anônimos e do Al-Anon, irmandades paralelas, dirigidas aos dependentes de drogas e aos familiares e amigos de dependentes do álcool, respectivamente. Não raro, também é possível ver algum membro de A.A. durante a missa, fazendo a divulgação das reuniōes do grupo.

Durante a pesquisa, foi possível constatar, no chamado "livro de registro" ${ }^{\circ}$ e em conversas com o coordenador e com o responsável pela manutenção da sala de reuniões do grupo Sapopemba, um total de 86 pessoas registradas como membros ingressantes no grupo. Desses, 81 são homens e 5 mulheres. A presença maciça masculina é uma característica marcante dos grupos de A.A., o que também é confirmado por Garcia (2004, p. 57-60) em sua pesquisa no grupo Doze Tradiçôes, localizado no município de São Gonçalo, no estado do Rio de Janeiro.

Segundo as informações colhidas, dos 86 ingressantes, 37 deles se afastaram do grupo: 36 homens e uma mulher. A grande rotatividade de membros é outra característica presente no cotidiano da irmandade. ${ }^{9}$ No caderno de ingresso, é possível observar o seguinte quadro, referente ao tempo existente entre o ingresso no grupo e o afastamento dele:

\section{Quadro 1 - Tempo entre ingresso e afastamento em A.A.}

Tempo decorrido entre o ingresso no grupo e o afastamento dele

Menos de 1 mês

entre 1 mês e 6 meses

entre 7 e 12 meses

entre 13 e 18 meses

entre 19 e 24 meses
Número de membros 
Em relação aos membros que mantêm um vínculo permanente com a irmandade, é possível estabelecer o seguinte quadro, segundo os registros mantidos pelo grupo:

\section{Quadro 2 - Tempo de permanência no grupo}

Tempo de permanência no grupo

até um 1 ano

entre 2 e 5 anos

entre 6 e 10 anos

entre 11 e 15 anos

entre 16 e 20 anos

mais de 20 anos
Número de membros

11

17

2

9

7

3

Por meio da observação das atividades do grupo e também dos registros em seu caderno de presença, constatou-se que, nas reunióes de recuperação, há uma frequiência média de 15 membros. Entre aqueles com os quais conversei, 18 no total, apenas um tem menos de 40 anos. Os demais estão em uma faixa etária que varia entre 40 e 73 anos. Esse dado também é confirmado por Garcia, que vê nele um indício de que a "maturidade física" é um fator relevante na "percepção das perdas e na decisão de filiar-se à associação" (2004, p. 59; grifo do original).

Todavia, se é certo que a elevada faixa etária dos AAs é um indicador de que a "maturidade física" favorece a percepção das perdas acumuladas durante o chamado tempo do "alcoolismo ativo", isso se deve também ao fato de que o uso considerado abusivo do álcool provoca efeitos danosos não só ao organismo do alcoólico, mas, sobretudo, à sua família. Logo, a elevada faixa etária parece também ser um indício da percepção do elo existente entre os planos físico e moral que envolvem a "doença do alcoolismo". 
Entre os membros que contatei, ${ }^{10}$ é significativo o número de aposentados (seis), os quais ainda continuam trabalhando em atividades informais, chamadas de "bicos", como forma de obter alguma renda. Destacam-se também cinco membros que não têm vínculo empregatício formal: um marceneiro, dois pedreiros, um sapateiro e um taxista. Em número menor (três), estão os que têm emprego formal: um assistente administrativo, um motorista e um zelador. Entre as mulheres, duas são "donas de casa", como elas próprias se consideram, uma é funcionária pública e uma está aposentada.

A associação do uso de álcool às massas trabalhadoras constitui uma referência consagrada no âmbito das pesquisas referentes aos sistemas de classificação e às relações de poder, que visam estabelecer formas de controle social sobre os membros das camadas populares ${ }^{11}$ (Neves, 2004, p. 11). Contudo, ao se priorizar a escolha de um grupo de A.A. sediado em um bairro popular, não se pretendeu, com isso, deduzir os significados elaborados em torno da doença do alcoolismo da condição social de seus membros. Trata-se, sim, metodologicamente, de analisar, a partir de um caso concreto, o modo como a fala da doença articula e mobiliza elementos do universo social no qual os AAs estão inseridos, permitindo-lhes atribuir um sentido à experiência do alcoolismo, ao mesmo tempo em que definem uma compreensão própria de si mesmos.

Durante os depoimentos, os AAs destacam, sobretudo, as perdas acumuladas na vida em família, durante o período ativo do alcoolismo. A esfera familiar é uma referência fundamental para os membros do grupo. É significativo que a maioria se tenha declarado casada. Entre os homens, nove se declararam casados, três, solteiros, e um, viúvo. Entre as mulheres, duas se declararam casadas, e duas, viúvas. À exceção dos solteiros, os demais declararam todos que têm filhos.

A metodologia de pesquisa contou, fundamentalmente, com a realização de entrevistas e com a observação de diversas atividades promovi- 
Edemilson Antunes de Campos. Contágio, doença e evitação...

das pela irmandade dos Alcoólicos Anônimos. Foram observadas as reuniōes de recuperação do grupo, além de outras atividades realizadas por ele, tais como encontros, reuniōes de serviços, reuniōes de unidade, reuniões temáticas, festas comemorativas do aniversário do grupo etc. Nesses encontros, os AAs narram uns aos outros, em verdadeiros depoimentos pessoais, feitos em primeira pessoa e chamados de "partilhas", as experiências vividas antes e depois da entrada em A.A.

Já as entrevistas foram individuais e semi-estruturadas, e aconteceram, em sua maior parte, em 2001 e 2002. Como forma de se obter um melhor controle sobre os dados coletados, realizamos outras, no final de 2004 e início de 2005. Ao longo da pesquisa de campo, também foram entrevistados familiares de um dos AAs, sua esposa e suas duas filhas, com a finalidade de avaliar as representaçôes elaboradas sobre o álcool, o alcoolismo e o programa de A.A., e suas repercussōes na vida familiar de um alcoólico. Essas foram as únicas entrevistas fora da sala do grupo.

A possibilidade de entrevistá-los ocorreu com a relação de afinidade estabelecida entre mim e Jorge. Fui convidado a ir à sua casa em um domingo para almoçar e depois "conversar" com sua esposa e suas filhas sobre o "problema que foi o alcoolismo". Durante a conversa com elas, Jorge se ausentou da sala, o que permitiu que ficassem "à vontade", como ele mesmo fez questão de frisar, para falar sobre os efeitos de seu alcoolismo na convivência familiar. Essas entrevistas também foram semiestruturadas, e os depoimentos foram todos transcritos.

As entrevistas individuais e com os familiares de um alcoólico foram fundamentais para a pesquisa, pois permitiram uma aproximação mais intensa com os membros do grupo. Com efeito, se nas reuniōes foi possível delimitar a fala a respeito da doença no interior do modelo terapêutico fornecido pela irmandade, nas entrevistas individuais foi possível estabelecer um maior controle sobre os dados, de maneira a compreen- 
der o modo como os alcoólicos elaboram uma compreensão própria do programa de recuperação e de como este repercute em suas vidas, possibilitando formular um sentido para a experiência do alcoolismo.

\section{O doente, o mal do alcoolismo e suas "causas"}

O A.A. é, de acordo com sua literatura oficial, "uma irmandade de homens e mulheres que compartilham suas experiências, forças e esperanças, a fim de resolver seu problema comum e ajudar outros a se recuperarem do alcoolismo" (Alcoólicos Anônimos, 1996). ${ }^{12}$ Seu modelo terapêutico é voltado, fundamentalmente, à recuperação individual e pessoal de seus membros, que "parecem ter perdido o poder para controlar suas doses ingeridas" (Alcoólicos Anônimos, 1996). O alcoolismo é entendido como uma "doença incurável, progressiva e fatal", de base "física e espiritual", que se caracteriza pela "perda de controle sobre o álcool", levando o alcoólico a beber de maneira compulsiva, podendo, com isso, conduzi-lo à "loucura" ou à "morte prematura".

O modelo terapêutico da irmandade também conta com a participação dos AAs em reuniōes periódicas, cujo objetivo é também ajudá-los a evitar o "primeiro gole" e, assim, a manter a sobriedade. As reuniōes podem ocorrer em salas alugadas ou cedidas por igrejas, escolas, instituiçôes correcionais ou de tratamento. As chamadas "reuniōes de recuperação" podem ser de dois tipos: "fechadas", compostas apenas por aqueles que se consideram "doentes alcoólicos", e "abertas", destinadas a todos aqueles que desejam conhecer a irmandade.

Nessas reuniōes, compartilham suas experiências, ajudando-se mutuamente a encontrar forças para superar a "doença alcoólica". Assim, quando chegamos a uma sala de A.A., seja para, por curiosidade, conhe- 
Edemilson Antunes de Campos. Contágio, doença e evitação...

cer as atividades do grupo, seja para buscar ajuda para o "problema" do alcoolismo, somos apresentados a um conjunto de idéias e de procedimentos formulados, dizem seus membros, para dar conta da "doença do alcoolismo" e ajudá-los a manter a sobriedade. Os AAs são unânimes em dizer que "aprenderam" isso depois que chegaram ao grupo: "Quando cheguei aqui, aprendi que era doente e impotente em relação ao álcool. Fiz minha parte e me mantenho sóbrio. Venho para não esquecer que não posso beber" (Jorge, reunião de recuperação aberta, 14 fev. 2002).

Embora outras associações de ex-bebedores compartilhem a idéia de que o alcoolismo é uma "doença", ${ }^{13}$ o A.A. exerce um papel fundamental na sedimentação desse conceito (Yalisove, 1998, p. 469-75), que assume uma feição particular em seu interior. A definição do alcoolismo elaborada pela irmandade pode nos ajudar a definir os contornos de sua teoria sobre a doença:

O que é o alcoolismo? Existem muitas e variadas interpretações sobre o que é realmente o alcoolismo. A explicação que parece ter sentido para a maioria dos membros de A.A. é que o alcoolismo é uma doença; uma doença progressiva e incurável. Como algumas outras doenças, porém, pode ser detida. Indo um pouco mais longe, muitos membros de A.A. acreditam que a doença representa a combinação de uma sensibilidade física ao álcool com uma obsessão mental pela bebida que, apesar das consequiências, não pode ser superada somente pela força de vontade. Antes de haverem sentido a influência de A.A., muitos alcoólicos que não conseguiam abandonar a bebida se consideravam moralmente débeis e possivelmente desequilibrados mentais. O A.A. acredita que os alcoólicos são pessoas enfermas, passíveis de recuperação se seguirem um simples programa, bem-sucedido para mais de 2 milhões de homens e mulheres. Uma vez que o alcoolismo se tenha fixado, não há pecado algum em ser doente. A esta altura, o livre-arbitrio inexiste e o sofredor já perdeu seu poder de decidir se continua a beber ou não. 


\section{Revista de Antropologia, São Paulo, USP, 2005, v. 48 No 1.}

O importante, porém, é encarar a realidade da própria doença e aproveitarse da ajuda disponível. Também é necessário que exista o desejo de recuperar-se. A experiência nos ensina que o programa de A.A. funcionará para qualquer alcoólico, quando este for sincero em seu desejo de parar de beber. Geralmente não funcionará para o homem ou a mulher que não estejam absolutamente seguros de que querem parar. (Alcoólicos Anônimos, s/d; grifos meus)

O alcoolismo é representado, inicialmente, como o resultado de uma articulação entre uma "sensibilidade física ao álcool" e "uma obsessão mental" em ingerir bebida alcoólica, que impede o alcoólico de parar de beber. Também é comum encontrarmos uma comparação entre o alcoolismo e uma espécie de "alergia ao álcool". ${ }^{14}$ Para A.A., é possível ser um alcoólico sem jamais ter bebido, bastando, para isso, não ter tido contato com a bebida alcoólica. Foi o que me disse Paulo, quando afirmou que: "Existem pessoas aí que nasceu, viveu aí 80 anos, ele é um alcoólatra só que ele nunca ficou bêbado. Por quê?? Porque ele nunca entrou em contato com bebida alcoólica. É essa predisposição orgânica" (entrevistado em 22 jul. 2002).

A teoria da doença de A.A., de acordo com Fainzang (1996, p. 34), representa o alcoolismo nos termos de uma "théorie de l'inné", própria a uma tradição biologizante largamente difundida nos Estados Unidos, segundo a qual ele é definido como uma doença inata, de base "genética", enraizada no organismo do alcoólico. Trata-se de uma "maladie de longue durée" (Saliba, 1982, p. 82); uma doença crônica de base orgânica e mental que independe da "força de vontade" do alcoólico para sua superação e controle.

Para os AAs, o indivíduo não é responsável pela aquisição da doença. Essa é remetida ao terreno da fatalidade e da aleatoriedade, pois independe tanto da vontade do indivíduo como da quantidade de álcool 
Edemilson Antunes de Campos. Contágio, doença e evitação...

ingerida. Como sublinha Marcos, 50 anos, casado, 18 anos de A.A., aposentado, membro do Escritório de Serviços Gerais de Alcoólicos Anônimos (ESG): "Um alcoólico não se torna alcoólico, ele é alcoólico" (entrevistado em 26 fev. 2002).

Mas a literatura de A.A. também define o alcoolismo como uma "doença espiritual", que se articula à dimensão propriamente moral do indivíduo, alterando seu comportamento, tornando-o "egocêntrico" e, com isso, afetando todas as dimensões de sua vida social. ${ }^{15}$ Em síntese, o alcoolismo é definido como uma doença, fruto de uma "predisposição física aliada a uma obsessão mental", e, ao mesmo tempo, uma "doença espiritual", que se restringe aos "limites mais restritos da pessoa" (Duarte, 1986, p. 144), isto é, ao plano intrapessoal: o indivíduo é aqui visto como totalidade "orgânico-espiritual". A teoria do alcoolismo engaja os indivíduos em toda sua complexidade físico-espiritual, apontando para as conexóes e os fluxos que perpassam a totalidade da pessoa em suas dimensões física (corpórea), mental e espiritual.

Embora não haja na literatura de A.A. a presença de um discurso etiológico explícito, ${ }^{16}$ é preciso lembrar que os membros das associações de ex-bebedores "têm na realidade quase sempre uma explicação a propor sobre seu alcoolismo, mesmo que eles se recusem freqüentemente a dizê-la quando são interrogados durante uma entrevista formal" (Fainzang, 1995, p. 73; tradução minha). Exemplo disso é a narrativa de Sônia, 66 anos, viúva, 15 anos de A.A., aposentada, na qual ela afirma que é uma "doente alcoólica em recuperação", pois cresceu num ambiente onde todos os irmãos bebiam - "Eu era a caçula entre sete irmãos e fui crescendo, meus irmãos todos bebiam, então eu fui crescendo naquele ambiente de cachaça; para mim era uma coisa normal beber" (reunião de recuperação aberta, 16 mar. 2002) -, sugerindo que é na esfera familiar que se "situam" as causas de sua doença. 
Revista de Antropologia, São Paulo, USP, 2005, v. 48 no 1.

Durante sua "partilha", na reunião citada, Sônia também fez referências aos "amigos de trabalho" que, na hora do almoço, a convidavam para beber uma dose - "Eu só bebia na hora do almoço, com aquelas amigas que eu arrumei lá na firma"-, e sugere ainda que o alcoolismo teria uma "causa" social, relacionada ao problema do desemprego:

Depois do último emprego que eu tive, eu vim a saber, dentro de uma sala de Alcoólicos Anônimos, que nessa doença a pessoa não pode ficar desempregada nem perder a família, eu vim [a] saber [disso] aqui dentro. (...) Depois que eu perdi esse emprego, com o dinheiro da indenização, eu falei: vou descansar um mês, depois eu continuo trabalhando. Mas que nada, companheiros, aí eu não consegui trabalhar mais. Eu vivia para beber. Já não conseguia trabalhar mais, não conseguia arrumar [trabalho], porque na situação [em] que eu fiquei, como eu ia procurar um emprego?

Fainzang (1989) aponta, em um estudo sobre a interpretação da doença em famílias de origens culturais diversas, que os esquemas interpretativos das causas das doenças são possíveis de ser expressos em quatro modelos, que podem conviver entre si numa mesma situação: a autoacusação, a acusação de um Outro próximo (familiar), a acusação de um Outro distante (estrangeiro) e a acusação da sociedade.

Pode-se dizer, então, que, no plano doutrinário, o modelo de interpretação do alcoolismo "situa" as "causas" da dependência do álcool no plano "físico" e "espiritual" do indivíduo, e não no exterior. Como lembra Fainzang (1989, p. 71; tradução minha), "este tipo de discurso está ligado à observância de códigos, tais como se vigiar, controlar-se, moderar-se", próprios a um esquema de interpretação da doença baseado na "auto-acusação", cujo objetivo é tornar o doente responsável por sua recuperação. ${ }^{17}$ 
Edemilson Antunes de Campos. Contágio, doença e evitação...

Já a narrativa de Sônia, por sua vez, remete aos esquemas de interpretação da doença, referindo-se tanto à "acusação do Outro próximo", na qual os amigos e familiares seriam os responsáveis pela "causa" da doença, como à "acusação da sociedade", quando afirma que o desemprego, sintoma de uma crise econômica e social, seria a "causa" do alcoolismo.

Ela também sugere uma reflexão sobre a maneira segundo a qual os significados da doença são construídos dentro de A.A., relacionando-os com os valores "família" e "trabalho", que englobam as relações sociais nas quais seus membros estão envolvidos. ${ }^{18}$ Nesse sentido, não é fortuito que Sônia sublinhe que "nessa doença a pessoa não pode ficar desempregada nem perder a família", uma vez que pode favorecer a progressão de seu alcoolismo. A perda de emprego, fruto de uma crise econômica e social, significa, aos olhos dos AAs, a possibilidade de perda da condição de "trabalhador", um drama que pode colocá-los em uma situação de liminaridade, capaz de conduzi-los ao "primeiro gole" e, conseqüentemente, ao desenvolvimento de seu alcoolismo. $\mathrm{O}$ mesmo pode ser dito em relação à "perda da família”, que significa a perda do plano relacional básico do qual se irradiam as marcas definidoras da identidade social dos membros do grupo. Logo, perder a família e o trabalho significa perder as referências fundamentais para a constituição de sua identidade, que tem nos papéis sociais de pai/mãe, esposo/a, trabalhador/a seus contornos fundamentais.

Mas como entender a existência de esquemas diferenciados de interpretação do alcoolismo no interior de A.A.? Garcia chama a atenção para o fato de que as narrativas dos membros "demonstram como o adepto da instituição dos Alcoólicos Anônimos constrói a sua trajetória como uma história coletiva que pode ser atribuída ao alcoólico" (Garcia, 2004, p. 160; grifo do original). Nesse sentido, pode-se dizer que a presença de esquemas interpretativos da doença diferenciados, no interior de A.A., é parte integrante do processo de construção de uma história coletiva, 
por meio da apropriação de aspectos pertencentes às trajetórias individuais. Com isso, os AAs podem integrar suas histórias individuais a uma nova ordem de significações, o que possibilita a reconstrução de sua identidade, reconhecendo-se como "doentes alcoólicos em recuperação", e permitindo, com isso, a elaboração de um sentido ligado à experiência do alcoolismo.

\section{Alcoolismo: uma doença física e moral}

É importante ressaltar, contudo, que a apreensão adequada desses modos diferenciados de interpretação do alcoolismo deve-se dar pela prática etnográfica e também pela análise dos aspectos simbólicos ligados ao par alcoolismo/doença. É assim que, em artigo anterior (Campos, 2004), analisamos os contornos da teoria da doença alcoólica em A.A., a partir do estudo das representações construídas sobre o alcoolismo, entendido como uma doença física e moral. É assim que, quando falam do alcoolismo, os AAs mobilizam um rico conjunto de categorias e expressões para significarem suas afliçôes e os efeitos do álcool sobre seu organismo, que, conseqüentemente, provocaram sua deterioração. Paulo relata esses efeitos nos seguintes termos:

Eu acordava de manhã e sentia aquelas dores na barriga, no estômago; eu precisava vomitar, e só depois que eu bebia aquilo passava. (...) Eu comecei a ter ânsia às três horas da manhã, constantemente. Mesmo se eu não tivesse bebido, vinha aquela ânsia. Me dava água na boca. Chegava oito e meia da manhã, não dava: eu tinha que beber para ficar legal. Já tinha que beber. Eu já bebia de manhã mesmo. Eu era muito relaxado com meu físico. (Paulo, entrevistado em 22 jul. 2002) 
Edemilson Antunes de Campos. Contágio, doença e evitação...

Ligada a essa sintomatologia orgânica, também se observa, na fala dos AAs, uma rica expressão de "sintomas" morais que apontam para os efeitos do alcoolismo no campo de relações nas quais o alcoólico está envolvido, notadamente no trabalho e na família.

Os membros do grupo evocam os efeitos do álcool e do alcoolismo sobre a família nos seguintes termos: "O bêbado é um ladrão da família"; "Eu tirava o prazer da família"; "O alcoolismo é uma doença da família". A doença do alcoolismo extravasa os limites do indivíduo para afetar, sobretudo, o núcleo relacional no qual o alcoólico está inserido, conduzindo-o a uma ruptura de seus laços familiares e de trabalho: "Quando bebia, perdia tudo e deixava de lado a família, os amigos, o trabalho"; "Quando bebia, eu não via meus filhos, eu não me relacionava com minha mulher. Perdia tudo. Só queria a bebida".

$\mathrm{Na}$ linguagem da doença formulada pelos AAs, o alcoolismo assume os contornos de uma perturbação físico-moral, ${ }^{19}$ afetando tanto o âmbito físico/orgânico como o âmbito relacional. A chamada doença do alcoolismo é traduzida tanto a partir de seus efeitos sobre o organismo, atingindo o âmbito físico e mental da pessoa, como a partir de seus efeitos sobre o plano moral, afetando, sobretudo, o âmbito relacional da família.

Os AAs dizem que, no tempo do alcoolismo ativo, eram "relaxados com o físico" - "Eu olhava no espelho e percebia que eu estava morrendo. Aquele rosto inchado e envelhecido pelo álcool..." (Paulo, entrevistado em 22 jul. 2002) - e necessitavam ingerir a bebida alcoólica para que as ânsias, as náuseas e os tremores cessassem.

As "alucinações", os "delírios" e os "tremores" são os signos mais característicos dessa fase, que denotam o alcoolismo como um estado de "dependência do álcool". O ato de beber já deixou de ser um ato de prazer e tornou-se uma necessidade orgânica: "Às vezes, eu saía de casa e dizia para mim mesmo que eu não ia beber, mas de repente, quando eu 
percebia, eu já estava com um copo na mão, bebendo" (Hélio, 63 anos, casado, 4 anos de A.A., pedreiro, entrevistado em 25 jul. 2002). Entre os signos da dependência, destacam-se os tremores: "Ás vezes eu acordava de manhã tremendo, minhas mãos não paravam, e só depois que eu bebia é que eu melhorava" (Paulo, reunião de recuperação aberta, 17 abr. 2002). "O tremor da mão é estigmatizado como a expressão tangível de um não-controle de si e, por extensão, de uma dependência” (Fainzang, 1996, p. 56; tradução minha).

A perda de controle (loss of control) sobre o álcool é narrada de maneira a enfatizar o estado de dependência em que se vive: "Eu percebi que eu estava dependente do álcool quando tentei parar de beber e não consegui. Eu não conseguia dar sustentação a esse parar de beber" (Paulo, entrevistado em 22 jul. 2002).

A perda de controle de si mesmo também é expressa por meio dos efeitos mentais do álcool, notadamente do chamado delirium tremens: as visões de animais, as alucinações, os delírios vividos pelo bebedor na fase ativa do alcoolismo. Nesse momento, o bebedor revela uma incapacidade em controlar seus pensamentos que, no limite, pode conduzir à própria "loucura", estágio final, ao lado da "morte prematura", o que os AAs indicam ser o "destino" daqueles que não procuram ajuda.

\section{O álcool, os nervos e o sangue}

As referências orgânicas que os AAs utilizam para falar sobre seu alcoolismo também sinalizam para o modo como a doença alcoólica afeta sua força e seu vigor, comprometendo a substância do corpo doente, enfraquecendo-o.

O par força/fraqueza é central para o reconhecimento de um funcionamento normal do organismo, mantendo uma ligação direta com as 
Edemilson Antunes de Campos. Contágio, doença e evitação...

representações criadas em torno das relações entre o "álcool", os "nervos" e o "sangue". A relação entre esses três elementos é parte freqüente das representações construídas pelos AAs. Paulo, por exemplo, deixa entrever o modo como o alcoolismo afetou seus nervos, enfraquecendo seu corpo:

Meus nervos me bloquearam. Eu fiquei na cama fazendo minhas necessidades - na cama, eu. Um cara barbudo, peludo como eu, virou criança. Eu não tinha mais forças. Minha mäe tinha que me limpar. Veja o ponto a que eu cheguei bebendo. (Entrevistado em 22 jul. 2002)

A literatura antropológica tem se ocupado dessa relação, ressaltando o modo como os indivíduos elaboram uma interpretação própria para os efeitos do álcool sobre os nervos bem como sobre suas conseqüências na vida social do bebedor. Seguindo o modelo sugerido por Setha Low (apud Fainzang, 1996, p. 70), os nervos são entendidos como uma categoria cultural, coletivamente construída, compondo um sistema simbólico, pelo qual os indivíduos podem expressar e significar suas afliçōes. ${ }^{20}$

Nessa linha, Fainzang (1996, p. 69-82) aponta para a complexidade dos elos que unem o álcool e os nervos nas representações dos ex-bebedores, membros do grupo Vie Libre, que constituem um esquema próprio de causalidade, elaborado para dar conta da doença do alcoolismo. Segundo a autora, esse esquema de "causalidade" pode ser expresso de duas maneiras, contraditórias entre si: ora os nervos "estão doentes" (p. 70) e são entendidos como a causa da alcoolização e do alcoolismo, ora eles são "afetados" pelo álcool, em decorrência de um beber considerado excessivo.

De todo modo, Fainzang compreende as referências aos nervos encontradas nas falas dos ex-bebedores como um indício, uma linguagem que denota o estado de dependência do bebedor: "Os nervos são idio- 
ma ou uma metáfora da perda de controle de si. Eles traduzem o fato de 'não ser mais si mesmo"' (1996, p. 73; tradução minha).

No Brasil, a temática dos "nervos" foi amplamente analisada por Duarte (1986 e 1994) em sua pesquisa sobre o processo de construção das identidades sociais e sua relação com a construção da noção de pessoa nas classes trabalhadoras urbanas no município de Niterói, no estado do Rio de Janeiro. O trabalho etnográfico realizado em torno da chamada "doença nervosa" conduziu o autor a uma compreensão dos "nervos" como um código cultural de expressão das camadas populares brasileiras. ${ }^{21}$

As referências aos "nervos" encontradas entre os trabalhadores urbanos configuram, segundo Duarte, um modo diferencial de ordenar e significar suas aflições, que redefine a compreensão que têm de si mesmos e da própria vida social. Nesse sentido, o código do "nervoso" se liga diretamente às representações construídas sobre a pessoa, operando como elemento mediador entre os planos "físico" e "moral".

A fala de Paulo, citada acima, parece conter os elementos que relacionam os efeitos do álcool sobre os "nervos" no campo das perturbações físico-morais. Em um primeiro momento, a ação do álcool compromete toda a substância corpórea, levando o alcoólico à total paralisia. Fraco e sem forças sequer para cuidar de si, ele se vê reduzido a um estado de dependência do outro - do cônjuge ou dos familiares.

O bloqueio dos "nervos", contudo, não traduz apenas um sintoma da "perda de controle de si mesmo", característico do estado de dependência do álcool, mas significa, sobretudo, o reconhecimento da incapacidade moral de assumir o papel social de "trabalhador" e, conseqüentemente, de prover o sustento da família.

Nessa medida, os "nervos" cumprem um papel fundamental, permitindo a comunicação entre os órgãos do corpo, regulando o funcionamento normal do organismo, ao mesmo tempo em que aparecem 
Edemilson Antunes de Campos. Contágio, doença e evitaÇão...

ligados diretamente ao âmbito moral de suas vidas, regulando o exercício dos papéis sociais vividos na família e no trabalho.

A comunicação entre os órgãos se faz por meio da ação do sangue que, por sua mobilidade, percorre todo o organismo, garantindo a unidade da substância corpórea. O álcool, porém, na visão dos AAs, é um líquido que "contamina" o sangue, comprometendo, sobretudo, os nervos, enfraquecendo e paralisando o alcoólico, que perde a capacidade de cuidar de si. Como lembra Fainzang.

O sangue é, ao mesmo tempo, vetor da impureza do álcool, que ele transporta até o cérebro e aos nervos, e, ele mesmo, uma das vítimas da intoxicação alcoólica. O sangue é entendido como uma substância que se difunde e nutre os outros órgãos. Desde o momento em que ele é infectado pelo álcool, tudo se passa como se os dois líquidos percorressem o mesmo trajeto. A substância-álcool se infriltra nas veias e termina por tomar o lugar do sangue. (1996, p. 76; tradução minha)

Mas, para os AAs, "perder o controle de si mesmo" significa, sobretudo, perder a qualidade moral de cuidar de si e de prover sua família por meio do trabalho. A articulação álcool/nervos/sangue e sua relação com a substância corpórea ligam-se, assim, ao plano moral, uma vez que incidem sobre a força física do alcoólico, colocando este que deveria cuidar de si e de sua família na condição de dependente do outro.

O alcoolismo é, então, uma doença cujos sintomas articulam os planos físico e moral da vida do alcoólico. Essa articulação é operada, sobretudo, através dos "nervos", que não só fazem a comunicação entre os órgãos do corpo, mas atuam como elemento mediador entre os planos físico e moral da vida do alcoólico. 
Uma imagem expressiva dessa mediação está associada à ação do álcool sobre os nervos, ligando-se à cena do bebedor que não tem controle sobre si mesmo e, conseqüentemente, não consegue manter-se em pé e dorme, freqüentemente, nas "ruas", caído no chão. É isso o que se depreende da fala de João sobre os tempos de seu alcoolismo ativo, em que muitas vezes não conseguiu entrar dentro da própria casa, dormindo na rua:

Eu senti que eu estava dependendo do álcool e que estava decadente. Foi quando, uma vez, cheguei em casa e não consegui abrir o portão para entrar, dormindo do lado de fora. Entre o pessoal que passava indo para o trabalho, me lembro de um cara que apontou o dedo para mim - eu vi, eu estava acordado, só não tinha força para levantar - e disse: "Olha o bêbedo onde dormiu". Aí eu senti que minha situação estava triste. (Entrevistado em 24 ago. 2002)

Essa fala é emblemática por vários aspectos. Fica claro, de um lado, como a "dependência do álcool" compromete a "força física" do bebedor, impedindo-o de se levantar e obrigando-o a dormir fora de casa. De outro, dormir na rua reforça o estigma pertencente à imagem do "bêbado" que não consegue entrar dentro da própria casa, em oposição à imagem do "trabalhador", do homem responsável, que acorda cedo para ir ao trabalho e prover o sustento de sua família.

Dormir na rua, nos bancos de jardins e praças, é um signo da ruptura com o suporte relacional da família, que dá ao alcoólico a possibilidade de se reconhecer como "homem digno". Não é a casa, como nos ensina Da Matta (1997), o espaço no qual nos construímos como pessoas morais, pertencentes a um grupo em que nos reconhecemos? A casa confere uma forte dignidade moral àqueles que nela habitam. Nela, o homem é reconhecido como "pai", "esposo", "chefe de família" e toda 
Edemilson Antunes de Campos. Contágio, doença e evitação...

uma ordem de categorias que, diferentemente da rua, lhe garante autoridade e reconhecimento. Como lembra Sarti, o uso do álcool pode comprometer, justamente, o exercício da "dignidade" do homem:

A casa é onde [se] realizam o projeto de ter uma família, permitindo (...) a realização dos papéis centrais na organização familiar, o de pai de família e o de mãe/dona-de-casa. Esse padrão ideal pressupõe o papel masculino de prover teto e alimento, do qual se orgulham os homens (...). Assim, para constituir a "boa" autoridade, digna da obediência que lhe corresponde, não basta ao homem pegar e botar comida dentro de casa e falar que manda. Para mandar, tem que ter caráter, moral. Assim, o homem, quando bebe, perde a moral dentro de casa. Não consegue mais dar ordens. (2005, p. $62-$ 63; grifos do original)

$\mathrm{Na}$ fala de João, dormir na rua significa fazer parte de um mundo indiferenciado e impessoal, do "mundo da rua" no qual se é "ninguém". $\mathrm{Na}$ rua, ele não encontra mais o lugar da autoridade que exerce na família. Sua tristeza reflete o sentimento de "fracasso", por não cumprir com sua "obrigação" de prover sua família com “teto" e "alimento", uma vez que os homens se sentem responsáveis pelos rendimentos familiares.

O alcoolismo assume, aqui, toda a dimensão de uma doença que articula os planos físico e moral da pessoa, impedindo o alcoólico de agir de modo "responsável". Quando falam da doença e dos dissabores enfrentados nos tempos do alcoolismo ativo, os AAs traçam os contornos precisos de uma imagem de si mesmos como "dependentes do álcool", isto é, como aqueles que perderam a responsabilidade relativa, ao mesmo tempo, a cuidar de si mesmos e a prover suas famílias por meio do trabalho. Com efeito, se o alcoolismo é uma "doença do indivíduo", ele é também uma "doença da família”. 
Revista de Antropologia, São Paulo, USP, 2005, v. 48 no 1.

\section{Uma "doença da família"}

Durante a pesquisa etnográfica, freqüentemente ouvi os AAs se referirem ao alcoolismo como uma "doença da família", um mal que atinge ao mesmo tempo o indivíduo e todos os que estão a seu redor, notadamente sua família e os presentes em seu local de trabalho, deteriorando os vínculos sociais e afetivos. Paulo confirma essa idéia ao relatar sua compreensão da "doença do alcoolismo":

Nós temos nossa terceira tradição que diz: "Para ser membro de A.A., o único requisito é o desejo de parar de beber". Agora, nem todos chegam em A.A. com esse desejo de parar de beber. A maioria chega aqui forçado, porque a doença, ela não é individual, a doença é da família, a doença é da coletividade. A doença é do indivíduo, só que, afetando esse indivíduo, ela afeta tudo. (Entrevistado em 22 jul. 2002)

Essa definição é significativa, pois indica com precisão a maneira pela qual o alcoolismo é entendido: como uma doença que extravasa o limite intrapessoal, afetando diretamente o núcleo relacional familiar do alcoólico. O alcoolismo provoca a decadência física e moral do alcoólico, levando-o à perda da família e da inserção na sociedade e no mercado de trabalho: "Aqui [em Sapopemba] muitos são desempregados, principalmente aqueles que chegam a Alcoólicos Anônimos. Através do alcoolismo, eles perderam seus empregos, perderam suas familias, eles chegam aqui todos detonados" (Paulo, entrevistado em 25 jan. 2005).

Mas como entender essa referência à ordem moral familiar no interior do modelo terapêutico de A.A.? Herzlich (1984) mostra que a linguagem da doença não é apenas a linguagem em relação ao corpo, mas sim à vida social e às relações sociais, nas quais o doente está envolvido. Para a autora: 
Edemilson Antunes de Campos. Contágio, doença e evitação...

A interpretação coletiva da doença se efetua nos termos que, em sentido próprio, acusam a sociedade ou a ordem social (...). Através de nossas concepções da doença, nós falamos de fato de outra coisa: da sociedade e de nossas relações sociais. É porque exige uma interpretação que a doença torna-se o suporte de um sentido, um significante cujo significado é a relação do indivíduo com a ordem social. (1984, p. 202; tradução minha)

Nesse sentido, as representações da saúde e da doença compóem um sistema de valores e de práticas que tanto inauguram uma ordem, no interior da qual os indivíduos orientam suas açôes em um determinado meio social, como asseguram a formação de um código comum - um campo semântico que permite a comunicação e as trocas simbólicas entre os membros de um determinado grupo social. As representações sobre a saúde e a doença são, então, parte integrante de um sistema classificatório regido por coordenadas físicas e morais, capaz de modelar e dar forma às aflições vividas pelos doentes.

Não é por acaso, então, que os alcoólicos constroem uma fala da doença na qual esta aparece associada aos conflitos com os valores e as regras da vida social, os quais envolvem, sobretudo, a esfera familiar e do trabalho. Mesmo sabendo que A.A. define o alcoolismo como uma "doença genética e orgânica", quando comentam o mal que os aflige, os AAs falam de si mesmos e dos conflitos vividos no meio social em que vivem. A fala da doença proporciona, então, uma linguagem por meio da qual os membros do grupo podem dar um sentido às suas aflições e aos conflitos enfrentados no âmbito relacional da família e do trabalho, que operam como valores estruturantes e englobantes do conjunto das práticas vivenciadas no meio social no qual os AAs estão inseridos.

As narrativas dos AAs sinalizam que a doença alcoólica é, sobretudo, uma "doença da família", na qual o dependente do álcool vive uma espécie de "falência da responsabilidade no cumprimento do dever" 
(Duarte, 1986, p. 259), de maneira que o alcoolismo faz " brotar a irresponsabilidade nos territórios por excelência da responsabilidade, notadamente, a família e o trabalho" (Campos, 2004, p. 1.385).

Em entrevista, João deixa entrever a maneira como o alcoolismo atinge o "homem alcoólico", afetando seus laços sociais, sobretudo, na família e no trabalho:

$O$ alcoolismo me afetou principalmente na família e no trabalho. Primeiro com a família, porque eu passei a ser aquele homem descompromissado; aquele homem com quem não se pode contar. Isso me criou um problema muito sério, pois a própria família não acreditava mais em mim, e eu também não. $O$ alcoolismo me atrapalhava. A bebida passou a ser dona da minha vontade. Eu não tinha mais vontade própria. Embora eu não quisesse, mas ela me levava a beber. Ai eu perdia completamente a noção daquilo que eu queria fazer. Na fábrica foi a mesma coisa: eu tinha minhas atribuiçôes junto aos demais companheiros mas, de acordo com minha bebedeira, ninguém podia contar comigo. Eu passei a ser um homem inútil na equipe. E ai eu sinto que eu mesmo perdi o domínio, perdi a credibilidade, eu perdi o interesse, eu perdi a força de vontade, eu perdi a força física. (João, entrevistado em 24 ago. 2002)

Na fala acima o alcoolismo é representado, notadamente, como a falência da "força física" e da "responsabilidade", constrangendo a vontade do alcoólico - "A bebida passou a ser dona da minha vontade. Eu não tinha mais vontade própria" -, impedindo-o de assumir os papéis sociais de "pai", "esposo" e "trabalhador".

Grande parte da tematização sobre o alcoolismo, particularmente entre os homens das camadas populares, passa, ao mesmo tempo, pelas questôes da "responsabilidade" e da "força física", de maneira que o uso do álcool ocupa um papel ambíguo, operando ora como um "estimulan- 
te" para trabalhos mais pesados e menos qualificados ora como um problema que compromete a responsabilidade no cumprimento do dever. O alcoolismo "afeta", sobretudo, as relações do alcoólico na família e no trabalho. A dependência do álcool, que atinge o doente, abala a "força física" do alcoólico, prejudicando o exercício de sua responsabilidade como "pai" e "trabalhador". Mas deixar de trabalhar significa, sobretudo, não cumprir seu papel moral de "homem provedor". Pois, como lembra Sarti (2005), "na moral do homem, ser homem forte para trabalhar é condição necessária, mas não suficiente para a afirmação de sua virilidade. Um homem, para ser homem, precisa também de uma família" (2005, p. 95; grifos do original). Ou seja, ele deve assumir a condição de "chefe de família", isto é, a condição daquele que tem a obrigação moral de provê-la por meio de seu trabalho.

Entre os membros das camadas populares, a família é pensada como uma ordem moral, operando como uma referência simbólica central, a partir da qual se formula e se organiza a produção dos significados sobre a existência e sobre a vida social. Como sublinha Sarti, "a família como ordem moral (...) torna-se uma referência simbólica fundamental, uma linguagem através da qual os pobres traduzem o mundo social, orientando e atribuindo significados a suas relações dentro e fora de casa" (2005, p. 86; grifo do original).

$\mathrm{Na}$ narrativa de João, então, perder a força física significa a perda de sua condição de "provedor" da família. O uso da bebida compromete a sua vida física e moral, representada, particularmente, pela perda de suas qualidades morais e de suas responsabilidades, notadamente, como "pai", "esposo" e "trabalhador". 
Revista de Antropologia, São Paulo, USP, 2005, v. 48 No 1.

\section{O alcoolismo é uma "doença contagiosa"?}

A categoria "doença da família" sugere ainda uma discussão sobre a natureza "contagiosa" do alcoolismo. Freqüentemente, os AAs dizem que seu alcoolismo provocou danos "físicos" e "morais" em seus familiares: "Eu tenho um filho que é doente mental, acho que fui eu que criei essa doença nele, por causa do álcool". Ou ainda: "Minha mulher está nervosa, ficou neurótica com meu problema de alcoolismo".

As queixas se estendem aos cônjuges e filhos, que também se reconhecem como "vítimas" do alcoolismo, o que dá a este uma dimensão não apenas individual, mas também coletiva. Exemplo disso é uma carta escrita pela filha de um membro do grupo, à qual tive acesso durante a pesquisa, na qual se pode ler: "Quando você desce para o bar, eu morro de preocupação, porque, se você chegar ruim, será mais um dia de briga; olho no relógio de 5 em 5 minutos. A minha mãe às vezes chora de nervoso" (carta escrita em 14 mar. 2002). Ao final da carta, a filha pergunta: "Será que você não se cansa de viver em brigas com a familia?”. A esposa de Jorge também se refere à influência do alcoolismo de seu marido sobre seu "corpo" e sua "família": "Eu vivi quase 18 anos em depressão, depressiva; eu não ligava muito para a casa, não ligava para os filhos, eu comecei a largar tudo também. Meu medo era que meus filhos começassem também a beber" (Antônia, 46 anos, cabeleireira, entrevistada em 8 set. 2002).

Mas o alcoolismo é uma "doença contagiosa"? Quando indagados sobre o assunto, os AAs apontam que é na "família" e nas relações de "trabalho" que o alcoolismo se mostra mais "contagioso". Paulo vai além e traça um paralelo sugestivo entre o alcoolismo e a Aids:

Eu vejo o pessoal preocupado com a Aids e há realmente a necessidade de ter essa preocupação com a Aids, porque é uma doença também supercontagiosa. Mas o alcoolismo é mais contagioso do que a Aids. Por exemplo, se eu fosse um 
Edemilson Antunes de Campos. Contágio, doença e evitação...

aidético, eu só transmitiria minha doença para uma outra pessoa se eu tivesse um contato direto. E o alcoólatra? É indiretamente que ele atinge as pessoas. $E$ indiretamente que aquela empresa, em que aquele alcoólico trabalha, começa a não produzir. Ele tá afetando os companheiros de trabalho. E há o contágio dentro da própria casa. Porque o alcoolismo é a doença da família. (Paulo, entrevistado em 22 jul. 2002)

As palavras de Paulo são importantes, pois sugerem pistas que podem nos ajudar a pensar uma "teoria cultural do contágio" a propósito do alcoolismo, distante das acepções biomédicas. Seguindo a trilha aberta por Douglas (1992), na pesquisa em que examina a elaboração de uma "teoria cultural do contágio", no contexto da Aids, Fainzang afirma que uma teoria do contágio no contexto do alcoolismo deve partir "do exemplo de uma doença não contagiosa de um ponto de vista médico, para mostrar suas características contagiosas nas representaçóes dos sujeitos e, por extensão, o que pode exprimir a idéia de contágio de um ponto de vista antropológico" (1996, p. 93; tradução minha). Nessa linha, "a definição antropológica da idéia de contágio deve se liberar de suas dimensões médicas e dar conta das representações, as quais ela converte em objeto de estudo, visando propor uma nova acepção".

Ora, uma doença não contagiosa, do ponto de vista médico, pode assumir um caráter contagioso nas representações formuladas pelos que a portam. É exatamente isso que Paulo sugere ao propor uma comparação entre o alcoolismo e a Aids. Essa comparação carrega importantes representações sobre o problema do "contágio" e da "transmissão" tanto da Aids como do alcoolismo. Assim, ao contrário do que supóem as concepções biomédicas, que circunscrevem o contágio ao âmbito biológico e fisiológico, atestado clinicamente, Paulo supõe que o alcoolismo, embora não seja transmitido, possa ser contagioso, afetando, sobre- 
tudo, aqueles que são mais próximos do alcoólico, isto é, seus familiares, seus amigos e seu ambiente de trabalho.

O modelo de contágio presente nas representaçōes formuladas por Paulo difere, então, da idéia de uma contaminação direta. Ou seja, ele não sugere que os familiares e amigos do alcoólico passem a beber como o doente, mas sim que eles sejam afetados pela doença do bebedor. Essa definição do contágio mostra-se, portanto, plenamente coerente com a teoria da doença alcoólica de A.A., uma vez que, sendo o alcoolismo considerado uma "doença inata e incurável", não pode ser transmitido a ninguém. $\mathrm{O}$ "contágio" só é possível ocorrer na forma da afetação, principalmente, da esfera familiar e do ambiente de trabalho do alcoólico.

Assim, pela ótica das representações do contágio presentes na narrativa de Paulo, opera-se uma inversão entre o alcoolismo e a Aids: enquanto o alcoolismo seria "contagioso", mas não transmissível, a Aids seria "transmissível”, mas não contagiosa. ${ }^{22}$

Nas representaçóes sobre o contágio formuladas pelos AAs, por seus cônjuges e filhos, encontram-se "sintomas" que se referem principalmente aos "nervos", sinalizando o modo como o alcoolismo afeta os familiares do doente alcoólico. É, portanto, através de "sintomas", tais como o "nervoso", a "angústia", as "neuroses", a "depressão", a "doença mental", a "violência doméstica" etc., que o alcoolismo se revela como uma "doença da família”.

\section{A lógica do contágio em A.A.}

Diante desse quadro, qual é a lógica subjacente à concepção de contágio elaborada pelos AAs e seus cônjuges? Como a "doença da família" afeta a entourage do bebedor? 
Edemilson Antunes de Campos. Contágio, doença e evitação...

Fainzang chama a atenção para o fato de que o "contágio" provocado pelo alcoolismo pressupõe não apenas uma proximidade "física", mas também "social":

Se as condiçôes de possibilidade do contágio comportam a divisão de um mesmo espaço físico, do mesmo ar, elas implicam, além disso, necessariamente, a divisão de um mesmo espaço social. A transmissão da doença de um corpo a outro não se faz ao acaso, pela simples proximidade corporal. É necessário que haja uma proximidade social, sendo aquela do cônjuge exemplar a esse respeito, uma vez que ele divide com o bebedor não apenas o mesmo ar, o mesmo espaço doméstico, poluído pelo hálito do bebedor, mas também o mesmo destino - o espaço doméstico sendo superposto ao laço matrimonial ou àquele criado pela vida comum. (1996, p. 87-88; tradução minha)

É dentro do ambiente familiar, no qual bebedor e cônjuge compartilham o mesmo "teto" e dividem o mesmo destino, que o "contágio" vai se manifestar mais intensamente. É nele também que bebedor e cônjuge, juntamente com seus filhos, dividem não só o mesmo "ar", mas também as mesmas dores e angústias provocadas pela doença. Nesse sentido, o contágio opera integrando a dimensão "física" e "moral" do alcoolismo, de maneira que seus vetores principais são o "odor" e, mais particularmente, o "hálito" do alcoólico. ${ }^{23}$ Vários membros do grupo de Sapopemba salientaram as queixas feitas por suas esposas devido ao mau cheiro exalado durante o alcoolismo ativo: "Minha esposa reclamava do meu mau cheiro, já que eu não tomava banho". Ou ainda: "Às vezes eu bebia e chupava uma bala para tirar o cheiro. Mas, certo dia, eu cheguei em casa e minha esposa disse: 'Você bebeu hoje.' Eu disse que não, mas ela sentiu o cheiro. Acho que é pelo nariz que esse cheiro sai" (Jorge, entrevistado em 25 jul. 2002). 
Revista de Antropologia, São Paulo, USP, 2005, v. 48 no 1.

O cônjuge também se queixa dos odores exalados pelo alcoólico. A esposa de Jorge, por exemplo, afirma:

As vezes, ele chegava e eu é que tirava o sapato dele e botava ele na cama, senão ele dormia no chão. (...) Tinha dias que ele chegava e, do jeito que estava, deitava na cama, fedendo, e eu tinha que agüentar aquela coisa horrorosa, podre, mas eu aceitava. Mas chegou uma hora que eu não aceitei mais. (Antônia, entrevistada em 8 set. 2002)

É o odor exalado pelo alcoólico que revela seu estado patológico e, conseqüentemente, a poluição/impureza de seu corpo. Como sublinha Fainzang:

A esposa percebe seu corpo invadido, investido pelo álcool, o qual ela teme carregar o traço: o odor. O odor do bebedor (exemplificado por seu hálito) é, ao mesmo tempo, o testemunho de seu estado patológico (ele é um signo que os cônjuges tomam (...) para diagnosticar uma recaída) e da impureza do corpo do bebedor. Desde então, o contágio é tanto dessa impureza como da doença. (1996, p. 88)

Nessa perspectiva, mesmo na ausência de relações sexuais ou de qualquer contato físico entre os cônjuges, o alcoolismo pode ser "contagioso" devido, fundamentalmente, ao laço social estabelecido entre o casal. Ou seja, no alcoolismo "o 'contágio' não se faz pelo sangue ou esperma, mas pelo laço social” (Fainzang, 1996, p. 94); o contágio se manifesta pela vivência comum entre o alcoólico e sua família.

O cônjuge também reconhece que a impureza do álcool "contamina" os laços familiares, deteriorando-os. É o que sugere a esposa de Jorge: "A bebida é um problema para qualquer família - é uma doença, realmente. A bebida afeta seu emocional, o lar, o alicerce que você planeja 
Edemilson Antunes de Campos. Contágio, doença e evitaÇão...

construir, ele volta a zero. A bebida não mexe só com ele, ela mexe com todos" (Antônia, entrevistada em 8 set. 2002). Ela relata também que o marido costumava beber em casa, causando danos a toda a família: "Ele trazia a bebida e guardava. Quando a gente menos esperava, ele já estava bêbado. Foi uma vida muito dolorosa para a gente".

Como reação a essa situação, os familiares se afastam, ou surgem ameaças de separação, que demoram ou nunca chegam a se concretizar. É preciso lembrar, como o faz Fonseca (2004), que o casamento é, entre os membros das camadas populares, um signo de status para a mulher, cuja auto-estima advém quase que exclusivamente "de suas tarefas domésticas na divisão do trabalho: ela deve ser uma mãe devotada e uma dona de casa eficiente" (p. 31), o que, muitas vezes, leva a esposa a suportar as agressóes e hostilidades provocadas pelo alcoolismo de seu marido.

Paulo, por exemplo, narra que sua mulher foi embora, após as sucessivas "brigas do casal":

Em relação à minha família, eu percebia que eu estava perdendo minha mulher, que eu estava perdendo meus filhos, eu sentia que estava perdendo. (...) $E$ a mesma coisa de você estar com a mão cheia de areia e você sentir a areia escapar pelos seus dedos. O relacionamento com minha esposa... Eu sempre fui desses bêbedos agressivos, não tinha limite, a ofendia sempre. Até o dia em que minha mulher foi embora - ela e meus filhos foram embora. (Entrevistado em 22 jul. 2002)

É comum ouvirmos relatos que indicam que as esposas, como forma de protestar e para rejeitar essa situação de submissão, passaram a se negar a dormir na mesma cama do marido alcoolizado, o que não deixava de provocar a irritação do alcoólico: "Eu passei a beber pesado e comecei a implicar com a mulher. Minha mulher não agüentava o cheiro, o bafo de 
Revista de Antropologia, São Paulo, USP, 2005, v. 48 no 1.

bebida, e eu queria ter relação e ela não aceitava. Ela começou a dormir em outra cama, e eu ficava revoltado" (Valter, 50 anos, casado, 3 anos de A.A., zelador, entrevistado em 24 jul. 2002).

Antônia diz que passou a dormir no quarto de sua filha: "Eu cheguei a falar para ele ir ao A.A. e que, se ele não parasse de beber, eu iria me separar dele. Eu cheguei a me separar fisicamente dele. Foi preciso. Eu passei a dormir com minha filha" (entrevistada em 8 set. 2002). Nesse instante da entrevista, a filha, que estava sentada ao lado de sua mãe, passa a narrar a reação violenta do pai:

Já fazia um tempo que minha mãe estava dormindo comigo, tentando fazer com que ele fosse ao A.A. para ela voltar a dormir com ele, mas ele não queria. Teve um dia que ele disse que não estava mais agüentando aquela situação e saiu. Depois ele voltou, e eu acho que tinha bebido alguma coisa, porque já voltou alterado. Ai, ele foi para meu quarto, onde minha mãe estava dormindo comigo, e foi com tudo e quebrou a porta, querendo pegar minha mäe à força. Nesse dia, apareceu até a polícia em casa. Ele quebrou a mesa, quebrou a cadeira. Ele foi superagressivo. (Bruna, 20 anos, balconista, entrevistada em 8 set. 2002)

Dormir no quarto da filha, separada de seu marido, é um signo da reação da esposa que, embora não tenha forças para se separar definitivamente, se nega a se submeter às agressōes praticadas pelo marido. Dessa maneira, além de uma reação à impureza do corpo do alcoólico, o cônjuge também reage ao "contágio moral" provocado pelo alcoolismo, que afeta sua família e cujos efeitos conduzem às agressóes físicas e à violência doméstica. Na seqüência, Antônia me diz ainda que, depois desse dia, ela procurou um advogado, para encaminhar a separação de seu marido. Diante da decisão de sua esposa, Jorge resolveu procurar a ajuda em A.A. 
Edemilson Antunes de Campos. Contágio, doença e evitação...

\section{O sistema de evitações de Alcoólicos Anônimos}

Todo o esforço do modelo terapêutico de A.A. será, portanto, o de combater o "vetor" do alcoolismo, isto é, o álcool. É isso o que sugerem os membros do grupo: "Numa sala de A.A., a gente só fala de álcool. O álcool está todo dia aqui. Ele está lá fora, mas ele está aqui dentro também. Ele éo nosso maior inimigo. Nós temos que falar dele, para lembrarmos que ele existe" (Valter, entrevistado em 24 jul. 2002). Não por acaso, "evitar o primeiro gole" é a máxima que norteia o comportamento do doente alcoólico em recuperação, contribuindo para engajar todos os membros do grupo em torno do valor e do princípio da abstinência - única maneira concebida para combater o alcoolismo e seus efeitos físicos e morais. Em outras palavras, é por meio da abstinência total do uso do álcool que se pode manter a pureza do sangue, responsável, como vimos, por garantir o funcionamento e a unidade da substância corpórea do alcoólico, assegurando a força e o vigor do alcoólico.

Contudo, não basta somente evitar o uso do álcool. É preciso, também, dizem os AAs, evitar tudo o que está relacionado à bebida alcoólica. O álcool, entendido como portador da impureza, "contamina” também os locais onde é consumido. É por isso que o programa de recuperação do alcoolismo também é chamado pelos AAs como um "programa de evitaçôes", no qual o doente deve evitar "os velhos hábitos", "os velhos amigos" e "os antigos lugares" que estava acostumado a freqüentar nos tempos do alcoolismo ativo.

A representação do álcool como elemento "impuro" remete às análises de Douglas (2001) sobre as prescrições e proscrições que visam proteger os indivíduos da doença ou do mal nas sociedades tradicionais. Esse conjunto de "regras de evitação" descreve e organiza o mundo social, tornando possível estabelecer uma ordem em oposição ao caos com o qual se confronta a experiência vivida. Como mostra essa pesquisadora, 
Revista de Antropologia, São Paulo, USP, 2005, v. 48 no 1.

a propósito dos ritos de pureza e impureza, esse esforço de construção da ordem social pode ser compreendido "sobre dois planos, um funcional e outro expressivo":

Em um primeiro momento (...), os indivíduos procuram influenciar o comportamento de seus semelhantes. O poder político é geralmente precário, e os chefes primitivos não são exceções à regra. De sorte que suas pretensões legítimas se apóiam sobre sua crença nos poderes extraordinários que emanam de sua pessoa, das insígnias de sua função ou das palavras que eles pronunciam. Sendo assim, a ordem social é mantida graças às penas em que incorrem os transgressores (...). Essas penas são uma ameaça que permite ao indivíduo exercer sobre o outro um poder coercitivo (...). Essas crenças são uma linguagem poderosa de exortação recíproca. Concebe-se facilmente a utilidade das crenças relativas à poluição em um diálogo no qual cada um reivindica ou contesta um certo status na sociedade. Mas, quando essas crenças são estudadas mais de perto, descobre-se que os contatos considerados como perigosos carregam consigo uma carga simbólica. Certas poluições servem de analogias para exprimir uma idéia geral da ordem social. (Douglas 2001, p. 25)

As interdições relativas à pureza e à impureza asseguram uma inteligibilidade do mundo social, permitindo aos indivíduos atribuírem uma ordem de sentido que organize a experiência vivida. Nessa linha, como sugere Fassin, "os conjuntos de prescrições e proscrições próprios de cada sociedade revelam, simultaneamente, sua teoria e sua prática da ordem social, a maneira pela qual ela é representada e a forma pela qual ela se impõe" (1996, p. 211; tradução minha).

Ora, a evitação do álcool entre os AAs também revela uma forma específica de ordenação do mundo social, delimitando, por exemplo, os espaços que podem e que não podem ser freqüentados, e as pessoas com 
Edemilson Antunes de Campos. Contágio, doença e evitaÇão...

as quais se deve passar a conviver. Em várias entrevistas os alcoólicos em recuperação salientaram, sobretudo, a mudança nas relações familiares após a entrada em A.A. Exemplo disso é a seguinte narrativa de Jorge:

Antes de Alcoólicos Anônimos, eu só pensava no bar. Quando chegava do trabalho, eu não parava cinco minutos em casa e já ia para o bar. Muitas vezes eu chegava em casa bêbado, nem tomava banho, dormia de qualquer jeito. Quando acordava era aquela ressaca (...). Hoje eu chego em casa, beijo meus filhos, converso com eles, com minha mulher. Agora, por exemplo, eu estou pagando a formatura de minha filha. Hoje, sóbrio, eu consigo conversar com meus filhos. Tudo isso eu devo a Alcoólicos Anônimos. (Jorge, entrevistado em 25 jul. 2002)

Ao se reconhecer doente, portanto, o alcoólico em recuperação passa a (re)significar os espaços, nos quais se desenrola sua sociabilidade, entre, de um lado, o "bar", o "boteco", o espaço da "ativa", onde as relações eram mediadas pelo uso do álcool, e, de outro, o "grupo de AA", local das reuniōes de recuperação, e a "casa", espaço das relaçôes familiares, que são agora valorizados por ele.

A impureza associada ao álcool revela, assim, uma lógica classificatória que possibilita a construção simbólica da experiência do alcoolismo, dentro de uma ordem capaz de mantê-lo sob controle, ao mesmo tempo em que lhe possibilita o resgate dos laços rompidos nos tempos do alcoolismo ativo.

É isso também o que sugere Paulo: "Depois que eu conheci Alcoólicos Anônimos, eu passei a ter uma vida diferente. Depois de muito tempo separado, eu voltei a conviver. Hoje, com meu trabalho, eu consigo manter minha familia. É essa a condição que A.A. dá" (entrevistado em 25 jan. 2005). Ele recupera sua identidade social de "trabalhador" e de "chefe de família", ao mesmo tempo em que se reconhece na identidade de 
Revista de Antropologia, São Paulo, USP, 2005, v. 48 No 1.

"doente alcoólico", reafirmada por todos os membros do grupo, durante as reuniōes de recuperação. Dessa maneira, ao admitir que é portador da "doença crônica e fatal do alcoolismo", ele pode resgatar sua identidade social de "provedor", isto é, de homem responsável pelo cuidado de si e pelo de sua família.

Nesse contexto, ser um "provedor" é um signo da recuperação do alcoólico e de sua família. O modelo terapêutico de A.A. constitui-se, assim, num "sistema de evitaçôes" que possibilita ao alcoólico reconstruir os vínculos familiares e profissionais pelo cultivo de sua responsabilidade. Para os AAs, a responsabilidade não é uma categoria "ético-abstrata", mas sim a "responsabilidade-obrigação" para consigo mesmo e pelos atos cometidos nos tempos do alcoolismo ativo, sobretudo, se esses atos provocaram danos a terceiros, que deverão, agora, ser reparados. Em outras palavras: a responsabilidade é uma categoria relacional por excelência, um valor ético-moral que articula os planos físico e moral da doença alcoólica.

À imagem do "homem descompromissado", "dependente do álcool" e que tem sua vontade dominada pela bebida, contrapõe-se a imagem do "homem responsável", membro de A.A., que se responsabiliza pelo cuidado de si mesmo, ao mesmo tempo em que cumpre seus deveres em relação à sua família. Não por acaso, Paulo sintetiza nos seguintes termos o significado do alcoolismo, ligado às representaçóes sobre a doença e o contágio em uma associação de ex-bebedores: "A recuperação de um alcoólico significa também a recuperação de sua família".

Assim caminham os membros de Alcoólicos Anônimos: no dia-adia, evitando "só por hoje" o "primeiro gole". A cada noite, nas reunióes de recuperação, os AAs trocam uns com os outros palavras e abraços, na celebração de mais um dia de sobriedade, reafirmando sua identidade de "doente alcoólico em recuperação", ao mesmo tempo em que recuperam os laços familiares com a esperança de alcançarem a sobriedade. 


\section{Notas}

1 Nas páginas seguintes, seguindo a maneira pela qual os membros dos Alcoólicos Anônimos se referem à irmandade, utilizarei as siglas A.A., para me referir à irmandade dos Alcoólicos Anônimos, e AAs, quando me referir a seus membros. Para diferenciar das citaçôes, as falas dos AAs serão sempre grafadas em itálico.

2 Vale também recuperar a advertência de Neves (2004) sobre as dificuldades e os limites da investigação antropológica, no contexto da investigação sobre o alcoolismo, e a necessidade de se explicitar os contextos culturais e simbólicos com os quais se constroem os significados sobre as diferentes formas e maneiras de beber e suas interdições.

3 A irmandade de Alcoólicos Anônimos conta com 524 grupos em todo o estado de São Paulo, organizados em 56 distritos, divididos em 11 setores. No setor A (capital), existem 204 grupos de A.A., organizados em 19 distritos, segundo dados do Escritório de Serviços Locais - ESG/SP. Disponível em: <www.aa-areasp.org.br/ adm/grupos/listagem.asp?TIPO=DistritosGruposPorSetor\&ID=2> (acesso em 13/1/2005).

4 Segundo dados do IBGE e da Fundação Seade, o distrito de Sapopemba é o segundo distrito paulistano em densidade populacional, contando, em 2004, com 286.857 habitantes. Disponível em: <www.seade.gov.br/produtos/msp/dem/ dem9_008.htm> (acesso em 20/12/2004).

5 Atendendo à solicitação dos entrevistados, de preservação do "princípio do anonimato", os AAs são tratados, aqui, por pseudônimos.

6 Segundo dados do IBGE e da Fundação Seade, referentes ao Censo de 2000, $61,38 \%$ dos habitantes do distrito de Sapopemba vivem com uma renda familiar que oscila na faixa de dois a menos de dez salários mínimos. Já $18,08 \%$ da população vive com renda familiar inferior a dois salários mínimos. Disponível em: <http: //www.seade.gov.br/produtos/msp/ren/ren1_001.htm> (acesso em 20/12/2004).

7 Disponível em <www.seade.gov.br/produtos/msp/cul/cul1_002.htm > (acesso em 20/12/2004).

8 Embora não faça um controle rigoroso da freqüência às atividades, o grupo Sapopemba mantém um "livro de registro" no qual são anotados os nomes dos membros quando de sua entrada no grupo e, também, daqueles veteranos que con- 
tinuam participando de suas reuniōes. Os AAs me disseram que esse livro deve sua existência à "autonomia do grupo", que pode decidir manter um controle desse tipo, caso seus membros julguem necessário. Eles informaram, ainda, que, por meio desse livro, é possível saber a média de membros que freqüentam o grupo, facilitando o repasse da contribuição do grupo aos órgãos de serviços da irmandade. Além do livro de registro, há também um "livro de frequiência", que os membros assinam todos os dias, quando chegam às reuniôes.

9 Garcia (2004, p. 60-61) observa que, no grupo Doze Tradições, no ano de 2002, 5 membros não chegaram a completar um mês de permanência; 4 atingiram 9 meses; 18 estão entre 1 e 9 anos; 11 têm entre 10 e 19 anos; e 4 têm 20 e 29 anos de permanência. Os motivos aventados para o afastamento de um membro do grupo são, segundo comentários feitos por aqueles que permanecem, as chamadas "recaídas", situação em que o alcoólico volta a beber, a mudança para outros grupos ou a busca por outras opçóes de tratamento.

10 Como não foi possível entrevistar todos os membros do grupo, os dados apresentados referem-se àqueles com os quais mantivemos contato nos dias em que participávamos das reuniões de recuperação.

11 Para Neves (2004), um eixo de análise muito recorrente é aquele que associa o uso do álcool às massas trabalhadoras, enfatizando as situações de precariedade socioeconômica, aglutinando-se em torno da equação "pobreza, precariedade e alcoolismo", acabando por legitimar intervenções sobre esse contingente da população. Com efeito, "de um modo positivo, a associação tende a valorizar a relação entre precárias e adversas condições de trabalho e o uso sistemático ou abusivo de álcool. De um modo negativo, a associação tende a consagrar a articulação entre o uso abusivo de bebida alcoólica e a imprevidência individual, incompatível com desempenhos de papéis de esposo, companheiro e pai” (id., p. 11).

12 A irmandade dos Alcoólicos Anônimos nasceu em 1935, em Akron, no estado de Ohio, nos Estados Unidos, após uma conversa entre um corretor da Bolsa de Nova York e um médico, ambos conhecidos, respectivamente, como Bill Wilson e Bob Smith. Eles constataram que, por alguma razão até ali não bem compreendida, conseguiam ficar sem beber durante bons períodos depois que passavam algum tempo conversando e compartilhando seu problema. Após vivenciar uma verdadeira "experiência espiritual e experimentar fortes sentimentos de triunfo, paz e sereni- 
Edemilson Antunes de Campos. Contágio, doença e evitaÇão...

dade", segundo depoimento do próprio corretor, ele decidiu trabalhar para que outros alcoólicos se beneficiassem com a descoberta e montou os primeiros grupos.

13 Um exemplo disso está presente na associação francesa de ex-bebedores Vie Libre, fundada em 1953 e até hoje um dos mais atuantes movimentos antialcoólicos, que se define como "um movimento de bebedores curados, abstinentes voluntários e de simpatizantes, trabalhando contra o alcoolismo, contra suas causas e pela promoção dos ex-bebedores" (Fainzang, 1996, p. 17; tradução minha). Para a Vie Libre, o alcoolismo é uma doença cujas causas são sociais - a miséria e o desemprego etc. -, atingindo principalmente os homens das camadas populares e exigindo um engajamento na luta social e política para sua superação.

14 A idéia de que o alcoolismo seria o resultado de uma obsessão mental, aliada a uma alergia do organismo do alcoólico ao álcool, foi apresentada ao co-fundador de Alcoólicos Anônimos, Bill Wilson, pelo médico Willian Silkworth. Nas palavras do médico: "Acreditamos que a ação do álcool sobre estes alcoólicos crônicos é a manifestação de uma alergia, que o fenômeno da compulsão limita-se a essa categoria de pessoas e jamais acontece com o bebedor moderado médio. Essas pessoas alérgicas nunca podem, sem correr riscos, consumir álcool de qualquer espécie" (cf. Barros, 2001, p. 50-52).

15 Para A.A., o egocentrismo é "a raiz de todos os problemas" do doente alcoólico: "Não está a maioria de nós preocupada consigo mesma, com seus ressentimentos ou sua auto-piedade? [...] Acima de tudo, nós, alcoólicos precisamos nos libertar desse egoísmo. Precisamos fazê-lo, ou ele nos matará!" (Alcoólicos Anônimos, 1994, p. 82-83).

16 "O A.A. não se questiona sobre as causas de sua doença, não questiona se há diferenças entre alcoolismo primário e alcoolismo secundário, não questiona se há alcoólatras que podem voltar a beber socialmente, não questiona qual é o momento em que o alcoólatra deve parar de beber e, sobretudo, não questiona jamais a eficácia de sua filosofia de recuperação" (Barros, 2001, p. 57).

17 Esse modelo explicativo da doença vai diferenciar o modelo terapêutico de A.A. de outros sistemas de interpretação do alcoolismo, que o abordam, por exemplo, a partir de uma visão "religiosa". Mariz (1994) sublinha, em seu estudo sobre os pentecostais, que para estes o alcoolismo não é entendido propriamente como uma doença, mas identificado tanto às causas sociais como à influência do elemento 
sobrenatural, expresso pelo "inimigo oculto, o espírito maligno - o demônio" (1994, p. 216).

18 Duarte (1986) define a centralidade do "valor-família", na definição de um padrão cultural hierárquico entre os membros das camadas populares, fundamental para delinear os contornos da identidade social e da noção de pessoa em seu interior. Nessa linha, "o 'valor-família' abarca um certo número de qualidades distribuídas entre seus componentes e que lhe concedem sua preeminência enquanto foco da identidade social" (id., p. 175). Entre os membros das camadas populares, portanto, o "valor-trabalho" é encapsulado pelo "valor-família", centro irradiador e foco principal na definição da identidade no interior desse grupo social.

19 As "perturbações físico-morais" são entendidas, aqui, no sentido proposto por Duarte e dizem respeito "às condições, situações ou eventos de vida considerados irregulares ou anormais pelos sujeitos sociais e que envolvam ou afetem não apenas sua mais imediata corporalidade, mas também sua vida moral, seus sentimentos e sua auto-representação" (2003, p. 177).

20 Segundo Low, a categoria "nervos" é culturalmente elaborada a partir de três níveis: "(1) os sintomas são exprimidos conforme as modalidades culturais por meio do corpo como um sistema simbólico, (2) os sintomas são culturalmente selecionados e identificados no quadro da teoria da doença e das regras culturais da etiologia, e (3) os sintomas têm significações socioculturais baseadas nos valores da sociedade e no sistema social" (apud, Fainzang, 1996, p. 70, n. 1; tradução minha).

21 Para Duarte, "os nervos e sua corte de derivados, com suas respectivas esferas semânticas e sentidos diferenciais, atravessam todos esses infinitos recortes analíticos em que nos habituamos a conduzir o exercício de compreensão do social. Estavam em jogo as relações de trabalho assim como a sociabilidade vicinal, as representações da saúde assim como as religiosas, o jogo dos papéis familiares assim como a relação com as instituições e códigos dominantes; enfim, o quotidiano e o ritual, a norma e o desvio, a regra e o desempenho" (1986, p. 10).

22 Fainzang (1996, p. 93; tradução minha) indica que a classificação da Aids como uma "doença transmissível e não contagiosa" traduz, em grande medida, "o temor das reações de medo e de evitação que seu uso engendraria na população".

23 As representaçôes sobre o contágio a partir de "vetores" tais como o "odor" e o "hálito" remetem, como lembra Fainzang, "às teorias aéreas em virtude das quais o ar que envolve o ambiente transmite a doença de uma pessoa infectada para 
Edemilson Antunes de Campos. Contágio, doença e evitação...

outra que respira o mesmo ar, ou às teorias da contagiosidade, notadamente, a doutrina das emanaçôes corpusculares, às quais se associavam, nos séculos XVII e XVIII, a difusão dos odores corporais, pelos quais se explicava o contágio sem contato direto" (1996, p. 86; tradução minha).

\section{Bibliografia}

\section{ALCOÓLICOS ANÔNIMOS}

s/d Uma democracia que deu certo, Folder para divulgação.

1994 A história de como milhares de homens e mulheres se recuperaram do alcoolismo, São Paulo, CLAAB/Centro de Distribuição de Literatura de A.A. para o Brasil. 1996 O grupo de AA: onde tudo começa, São Paulo, JUNAAB/Junta de Serviços Gerais de Alcoólicos Anônimos do Brasil.

BARROS, L. F. 2001

A alquimia dos grupos anônimos de auto-ajuda, São Paulo, tese de doutorado, Universidade de São Paulo.

CAMPOS, Edemilson Antunes de

2004 "As representaçōes sobre o alcoolismo em uma associação de ex-bebedores: os Alcoólicos Anônimos”, Cad. Saúde Pública, 20(5): 1.379-1.387.

CEBRID (Centro Brasileiro de Informaçōes sobre Drogas Psicotrópicas)

2002 I Levantamento domiciliar sobre uso de drogas psicotrópicas no Brasil: estudo envolvendo as 107 maiores cidades do País — 2001, São Paulo, Universidade Federal de São Paulo/Senad.

DA MATTA, Roberto

1997 A casa e a rua: espaço, cidadania, mulher e morte no Brasil, 5.ed., Rio de Janeiro, Rocco.

DOUGLAS, Mary

Risk and blame. Essays in cultural theory, London/New York, Routledge. 
Revista de Antropologia, São Paulo, USP, 2005, v. 48 No 1.

2001

De la souillure: Essai sur les notions de pollution et le tabou, Paris, La Découverte. (Edição em língua portuguesa: DOUGLAS, Mary, Pureza e perigo: ensaio sobre as noçôes de poluição e tabu, trad. de Sonia Pereira da Silva, Lisboa, Edições 70, s/d.)

DUARTE, Luiz Fernando Dias

1986 Da vida nervosa da classe trabalhadora, Rio de Janeiro, Zahar.

1994 "A outra saúde: mental, psicossocial, físico-moral?”, in ALVES, Paulo Cesar \& MINAYO, Maria Cecília (org.), Saúde e doença: um olhar antropológico, Rio de Janeiro, Fiocruz, p. 83-90.

2003

"Indivíduo e pessoa na experiência da doença", Ciência e Saúde Coletiva, 8(1): 173-83.

FAINZANG, Sylvie

1989 Pour une anthropologie de la maladie en France: un regard africaniste, Cahiers de L'homme, Paris, Ed. de l'École des Hautes Études en Sciences Sociales.

1995 "Une anthropologie du dé-boire", Journal des anthropologues, 60, Montrouge, AFA-EHESS, p. 71-76.

1996 Ethnologie des anciens alcooliques: la liberté ou la mort, Paris, PUF.

FASSIN, Didier

1996 L'espace politique de la santé - essais de généalogie, Paris, PUF.

FONSECA, Claudia

2004 Familia, fofoca e honra: etnografia de relaçôes de gênero e violência em grupos populares, Porto Alegre, Editora da UFRGS.

GARCIA, Angela Maria

2004 E o verbo (re)fez o homem: estudo do processo de conversão do alcoólico ativo em alcoólico passivo, Niterói, Intertexto.

HERZLICH, Claudine

1984 "Médicine moderne et quête de sens: la maladie signifiant social", in AUGE, M. \& HERZLICH, C. (orgs.), Le sens du mal: anthropologie, histoire, sociologie de la maladie, Paris, Editions des Archives Contemporaines, p. 189-215.

JOVELIN, Emmanuel \& ORESKOVIC, Annabelle

2002 De l'alcoolisme à l'abstinence, Paris, Édition ASH. 
Edemilson Antunes de Campos. Contágio, doença e evitação...

MARIZ, Cecília Loreto

1994 "Libertação e ética: uma análise do discurso de pentecostais que se recuperaram do alcoolismo", in Nem anjos nem demônios: interpretaçôes sociológicas do pentecostalismo, Petrópolis, Vozes, p. 204-24.

MOTA, Leonardo Araújo

$2004 \quad$ A dádiva da sobriedade: a ajuda mútua nos grupos de alcoólicos anônimos, São Paulo, Paulus.

NEVES, Delma Pessanha

2004 "Alcoolismo: acusação ou diagnóstico?", Cad. Saúde Pública, 20(1): 7-14.

SALIBA, Chalif

1982 La cure de désintoxication alcoolique et ses prolongements, Lyon, Press Universitaire de Lyon.

SARTI, Cynthia Andersen

2005 A familia como espelho: um estudo sobre a moral dos pobres, São Paulo, Cortez.

YALISOVE, Daniel

1998 "The origins and evolution of the disease concept of treatment", Journal of Studies on Alcohol, jul., p. 469-75. 
ABSTRACT: The major aim of this article is to analyse the construction of the notion of alcoholic illness in an association of ex-drinkers: the Alcoholics Anonymous (A.A.). Basead on an ethnographic research carried with members of the Sapopemba A.A. group (located in a neighbourhood in the outskirts of S. Paulo City, Brazil) and family members, the role of this agency is stressed as a privileged place for anthropological study on alcoholism from an emic perspective, i.e., such as it is lived and managed by those who recognise themselves as "recovering alcoholic patients". At the same time, the possibility of "contagion" of the alcoholic illness is stressed, linked to representations built on alcohol and alcoholism. In fact, alcoholism is understood as a physical and moral illness which, besides hitting the person considered as ill, also affects the set of social relationships - both family and professional - in which he/she is involved. As a consequence, the A.A. therapeutic model is analysed as an "avoidance system" which allows the alcoholic person to build an order of senses inside which the symbolic construction of the experience of the illness is operated, the purpose of which is to enable control of the alcoholic illness and to recuperate social bonds - both within the family and at work - that got lost at the times of active alcoholism.

KEY-WORDS: Alcoholics Anonymous, alcoholism, illness, avoidance system, contagions cultural theory.

Aceito em setembro de 2005. 